\title{
The Effect Analysis of Reservoir Height Variations at the Pico- Hydro System to Charger a Laptop Battery
}

\author{
Syamsuri ${ }^{1}$, Hasan Syafik Maulana ${ }^{2}$, Wendy Candra Kusuma ${ }^{3}$ \\ Mechanical Engineering Department, Institut Teknologi Adhi Tama Surabaya ${ }^{1,2,3}$ \\ 100 Arief Rahman Hakim Street, Surabaya \\ Email: syam_sby2003@yahoo.com¹, hasan17sm@gmail.com²
}

\begin{abstract}
Energy has become a very serious problem in many countries, one of which is electric energy. Water is the latest energy that deserves to be developed and also utilized to the fullest. In addition to the source of our life, water is also an energy that can be utilized for a variety of things including the development of technology, such as the energy source for hydroelectric power generation such as pico hydro. An example of piko-hydro is a Pelton turbine that utilizes the flow of water from a height. Among other advantages, the power produced is large, simple construction, easy to maintain, the technology that is simple and easy to apply in isolated areas. In generating the maximum electric energy, research is conducted experimental studies of the influence of Pelton turbine head height variation of the electrical energy that is generated to turn on the laptop. The study was carried out in the ITATS H building using a variety of valve openings and head heights of $18^{\circ}, 36^{\circ}, 54^{\circ}, 72^{\circ}, 90^{\circ}$ and $17,12.5$, and 9 meters on Pelton turbines. Based on research and data analysis, the greatest electrical power is obtained, which is 3.96 Watts at variations of the valve opening $90^{\circ}$ and with a reservoir height of 17 meters. The maximum efficiency system achieved at the water reservoir height of the 17 meters with 90 valve openings is $14.56 \%$. The results of the electrical power produced by this Pelton turbine can be used to charge the laptop for 2.18 hours.
\end{abstract}

Keywords: Electricity, energy, pelton, pico-hydro, turbine.

\section{Introduction}

Energy has become a very serious problem in many countries, one of which is electric energy. The World Bank notes that $14 \%$ of the world's population still has difficulty accessing electricity, especially those in rural or remote areas [1-3]. In Indonesia, electricity is supplied from the National Electricity Company or commonly known as PLN, which electricity is obtained from hydroelectric power plants as well as from other energy sources. To make a large-scale hydroelectric power plant would need a great cost so that it can increase the costs that must be borne by the public as consumers. This is also compounded by access to remote areas that difficult road access makes installation cost of PLN's electricity installations also increasing, so it is necessary to find an alternative source of energy to another.
Water is the latest energy source that deserves to be developed and also utilized to the fullest. In addition to the source of our life, water is also an energy that can be utilized for a variety of things including the development of technology in view of the abundance of water in Indonesia. Indonesia is one of the countries that has a very large water supply according to the Food and Agriculture Organization (FAO) [4]. This makes Indonesia one of the countries that have a great opportunity to utilize energy derived from water. One alternative energy with the use of water that can be used is Pico-hydro, wherein Pico-hydro this uses a small scale hydroelectric power plant $[5,6]$. With their ability to generate electrical energy with small power, the pico-hydro can be applied to the ducts sewer, so that the flow of water that is not used can be recovered [7]. With the use of Pico-hydro, it will be able to help supply energy for 
electrical energy needs in the area with problem local geographic, economic and social condition with high efficiency $[6,8]$.

Pelton turbine or commonly called impulse turbine with the tangential flow is a turbine that uses kinetic energy to drive the propeller or blade that is on the runner with the flow sprayed from the nozzle. The nozzle increases the kinetic energy of the water flowing through the pipe, then in the outlet of the nozzle, the water comes out in the form of a jet and strikes the buckets (vanes) of the runners. Pelton turbines are often used in Pico-hydro installations, this is because Pelton turbines are capable of being used in moderate to high reservoir height variations so that making easy to use in varied conditions [9]. The use of pelton turbines for Pico-hydro technology has been widely reviewed by several researchers, as was done by Hery Irawan et. al. Valve opening variations and lamp loads were varied to determine the performance of Pelton turbines in the pico-hydro system analyzed in the study [10]. With a $90^{\circ}$ valve opening and a 9-watt lamp load, the largest electrical power can be obtained from the study with an electric power of 1,761 watts. In other studies with laptop loading and valve opening variations as Syamsuri et. al., shows that the magnitude of valve openings in Pelton turbine installations greatly affects the amount of electric power and efficiency produced [11].

From the literature studies that have been reviewed, valve openings and reservoir heights are analyzed in this study. This is intended to determine the value of electrical energy and also the efficiency value produced by the Pelton turbine system by loading the laptop.

\section{Research Methods}

In experiments conducted to produce energy in order to obtain a more optimal result, various variations of the height of reservoir tanks and variations in valve openings are used. Before determining reservoir height variations, several reservoir height variation experiments have been conducted to determine whether the power used is sufficient or not to supply energy by charging the lamp, where the variation in reservoir height is from 0 meters to 5 meters with the full valve opening, as shown in figure 1. From these variations it was found that at reservoir heights 0 to 2.5 meters the lights did not turn on at all, this was because the flow flowed so small that it was unable to turn the turbine generator. At reservoir height, 2.5 to 3.5 meters the lights produced are still dim, while at the height of the reservoir above 3.5 meters the lights are already bright. From the results of these comparisons, it can be said that with the height of the reservoir above 3.5 meters it will have enough power to supply electrical energy. So that the height variation used in this experiment is at the reservoir height of 17 meters, 12.5 meters and 9 meters by adjusting the height of the ITATS $\mathrm{H}$ building, while the valve openings used are $18^{\circ}, 36^{\circ}, 54^{\circ}, 72^{\circ}$, and $90^{\circ}$.



Figure 1. Corelation of lamp brightness level with hight reservoir tank

The scheme of the pico-hydro system used in this study is shown in figure 2. In the scheme, the Pico-hydro system uses Pelton turbines with a diameter of $22 \mathrm{~cm}$ and a Pelton width of $6 \mathrm{~cm}$, made from aluminum. The generator used in the system is able to produce 24 volt DC voltage that is subsequently connected to the battery and then distributed to the inverter to convert the voltage to 220 volts 
with alternating current (AC). The energy is then used to charge a laptop with an input power of 100-200 volts with a current of 1 Ampere (AC) and the frequency is 50-60 $\mathrm{Hz}$, while the output itself is $19 \mathrm{~V}$ and 1.75 Ampere (DC).

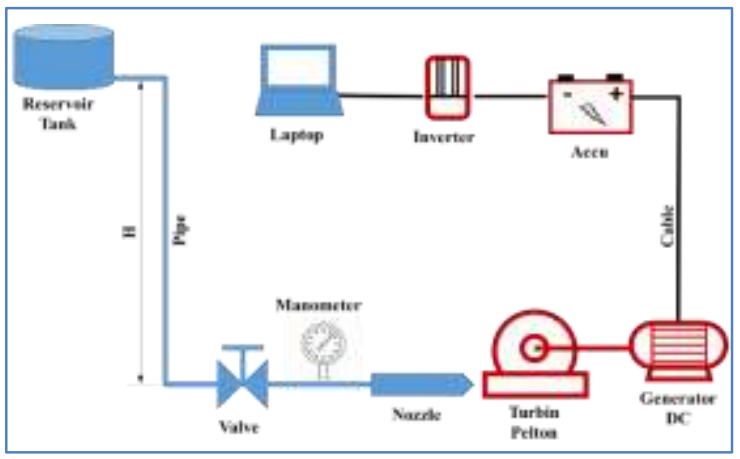

Figure 2. Schematic of pico-hydro system

Scheme of data collection in this study starts from the water flowed from the reservoir is at an altitude that varied by 17 meters, 12.5 meters and 9 meters to the valve. When water reaches the valve, the valve is opened with openings of $18^{\circ}, 36^{\circ}$, $54^{\circ}, 72^{\circ}$, and $90^{\circ}$ at each reservoir height variation. In each of the valve opening is taken of data: the pressure, the rotation speed of the turbine shaft and discharge Pelton, subsequently retrieved data also strong currents and voltages of these variations.

\section{Result and Discussion}

1. Correlation of Valve Openings To Discharge For Reservoir Height Variations



Figure 3. Effect of valve openings on discharge for various reservoir height variations
The effect of valve openings on discharge for various reservoir height variations is generally seen that with a larger valve opening, the resulting discharge is also large, as shown in figure 3. The figure shows that at the height of the reservoir 9 meters the water flow increases with increasing valve openings. With the smallest valve openings $\left(18^{\circ}\right)$ at the reservoir height of 9 meters, it produces $4.857 \times 10^{-5} \mathrm{~m}^{3} / \mathrm{s}$ while at the largest valve openings $\left(90^{\circ}\right)$ produces a discharge of $1.14 \times 10^{-4} \mathrm{~m}^{3} / \mathrm{s}$. Increased discharge also occurs at reservoir heights $12.5 \mathrm{~m}$ and $17 \mathrm{~m}$. With the smallest valve opening $\left(18^{\circ}\right)$ at the reservoir height of 12.5 meters, it produces a discharge of $5.41 \times 10^{-5} \mathrm{~m}^{3} / \mathrm{s}$ while at the largest valve opening $\left(90^{\circ}\right)$ produces a discharge of $1.26 \times$ $10^{-4} \mathrm{~m}^{3} / \mathrm{s}$. Whereas with the smallest valve opening $\left(18^{\circ}\right)$ at the reservoir height of 17 meters it produces a discharge of $7.05 \times 10^{-5} \mathrm{~m}^{3} / \mathrm{s}$ while at the largest valve opening $\left(90^{\circ}\right)$ produces a flow of $1.63 \times 10^{-4} \mathrm{~m}^{3} / \mathrm{s}$, for more details can be seen in table 1 . This is because when the valve is opened wide, the quantity of water flowing will be greater. According to the law Continuity that the quantity of water flowing is greater means that the discharge generated is also large. From the third reservoir height variations, it can be seen that at the same valve opening the 17-meter reservoir height produces the largest discharge from the reservoir height of 9 and 12.5 meters.

Table 1. Data from the comparison of the effect of valve openings on water discharge for various reservoir height variations

\begin{tabular}{cccc}
\hline \multirow{2}{*}{$\begin{array}{c}\text { Opening } \\
\text { Valve }\end{array}$} & \multicolumn{3}{c}{ Dischard $\left(\mathrm{m}^{3} / \mathrm{s}\right)$} \\
\cline { 2 - 4 } & $\begin{array}{c}\text { Head } \\
9 \mathrm{~m}\end{array}$ & $\begin{array}{c}\text { Head } \\
12.5 \mathrm{~m}\end{array}$ & $\begin{array}{c}\text { Head } \\
17 \mathrm{~m}\end{array}$ \\
\hline $18^{\circ}$ & $4.59 \mathrm{E}-5$ & $5.41 \mathrm{E}-5$ & $7.05 \mathrm{E}-5$ \\
\hline $32^{\circ}$ & $6.66 \mathrm{E}-5$ & $8.1 \mathrm{E}-5$ & $1.02 \mathrm{E}-4$ \\
\hline $54^{\circ}$ & $8.57 \mathrm{E}-5$ & $9.61 \mathrm{E}-5$ & $1.25 \mathrm{E}-4$ \\
\hline $72^{\circ}$ & $1 \mathrm{E}-4$ & $1.14 \mathrm{E}-4$ & $1.44 \mathrm{E}-4$ \\
\hline $90^{\circ}$ & $1.14 \mathrm{E}-4$ & $1.26 \mathrm{E}-4$ & $1.63 \mathrm{E}-4$ \\
\hline
\end{tabular}


2. Correlation of Valve Openings to shaft rotation for reservoir height variations

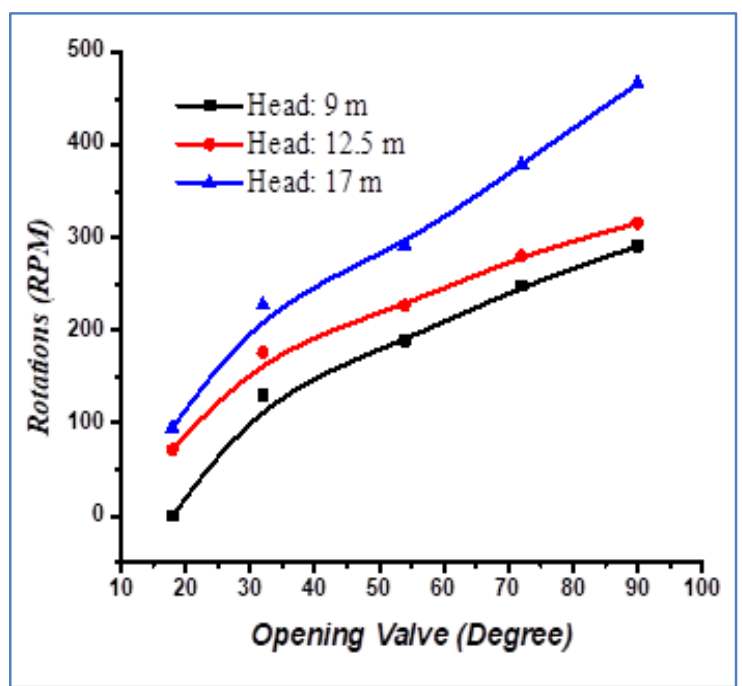

Figure 4. Effect of valve openings on shaft rotations (rpm) for various reservoir height variations

When the valve is opened wide, the quantity or discharge of the flowing water will be greater, this affects the shaft rotation (rpm) in the turbine. Because the more flowing water flows, the turbine rotation will be higher, as shown in figure 4 . In the figure, it shows the effect of valve openings on the shaft rotation at each of the different reservoir heights. With the smallest valve openings $\left(18^{\circ}\right)$ at a reservoir height of 9 meters, the turbine shaft does not rotate at all because the water discharge that comes out is very small while the largest valve opening $\left(90^{\circ}\right)$ produces a shaft rotation of 291 RPM. Similarly, the height of the reservoir 9 meters, at a height of 12.5 and 17-meter reservoir also experienced an increase in rotation on the turbine shaft when the valve is opened the greater. With the smallest valve openings $\left(18^{\circ}\right)$ at a reservoir height of 12.5 meters, it produces a turbine shaft rotation of 71 RPM while at the largest valve opening $\left(90^{\circ}\right)$ it produces a turbine rotation of 316 RPM. Whereas the smallest valve openings $\left(18^{\circ}\right)$ at reservoir height of 17 meters produce a turbine rotation of 95 RPM while at the largest valve opening $\left(90^{\circ}\right)$ it produces a turbine rotation of 466 RPM, for more details can be seen in table 2. This is in accordance with the Bernoulli equation in fluid flow, that the higher the reservoir $(\mathrm{h})$, the greater the potential energy produced so that it will affect the kinetic energy in pounding the motion blade or runner. With the increase in kinetic energy that hits the runner, the resulting rotation will be even greater.

Table 2. Data from the comparison of the effect of valve openings on shaft rotations (RPM) for various reservoir height variations

\begin{tabular}{cccc}
\hline \multirow{2}{*}{$\begin{array}{c}\text { Opening } \\
\text { Valve }\end{array}$} & \multicolumn{3}{c}{ Rotations (RPM) } \\
\cline { 2 - 4 } & $9 \mathrm{~m}$ & $\begin{array}{c}\text { Head } \\
12.5 \mathrm{~m}\end{array}$ & $\begin{array}{c}\text { Head } \\
17 \mathrm{~m}\end{array}$ \\
\hline $18^{\circ}$ & 0 & 71 & 95 \\
\hline $32^{\circ}$ & 130 & 176 & 227 \\
\hline $54^{\circ}$ & 189 & 227 & 291 \\
\hline $72^{\circ}$ & 248 & 281 & 379 \\
\hline $90^{\circ}$ & 291 & 316 & 466 \\
\hline
\end{tabular}

3. Correlation of Valve Openings to Electric Power For Variations in Reservoir Height

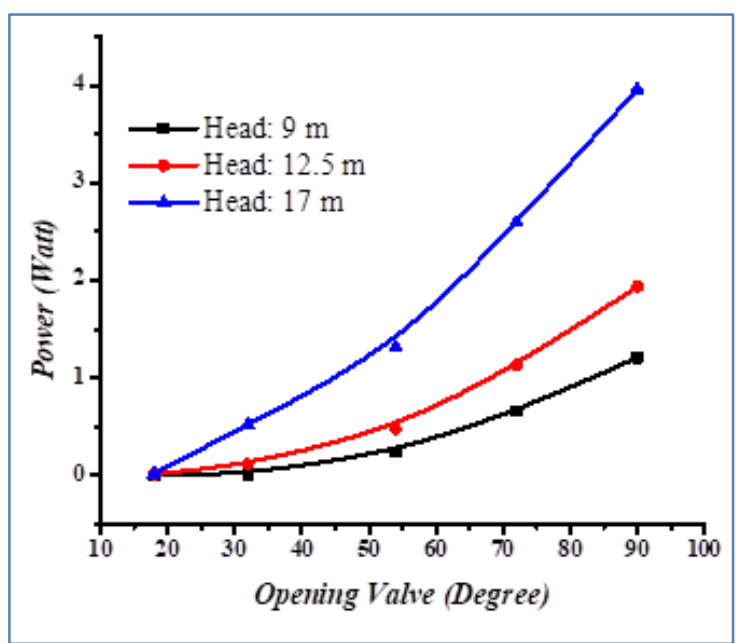

Figure 5. Effect of valve openings on electric power for various reservoir height variations

With increasing rotation with increasing the flow of water, then when the generator shaft Coupled with the generator would spin faster and faster so that electric power is generated is also the greater. The phenomenon is shown in Figure 5, where the figures show a comparison of the relationship between the reservoir height 
variation and variation of the valve opening of the electric power generated. When the valve is opened at the smallest openings $\left(18^{\circ}\right)$ at the reservoir height of 9 meters no power is generated. This is because the generator does not rotate because the flow of water is too small so it cannot rotate the generator shaft. Whereas at the largest valve opening $\left(90^{\circ}\right)$ at the reservoir height of 9 meters produces electric power of 1.209 Watts. With a reservoir height of 12.5 meters at the smallest valve opening $\left(18^{\circ}\right)$, it can produce a power of 0.013 Watt while at the height of the reservoir 17 meters with the same valve opening can produce 0.0208 Watt. From the above data, it can be said that with the smallest openings $\left(18^{\circ}\right)$ at the height of the reservoir 12.5 and 17 meters, it can produce electricity even though it is small. While the largest valve opening $\left(90^{\circ}\right)$ at 12.5-meter reservoir height produces electric power of 1.935 Watts. However, at the height of the reservoir of 17 meters with the same openings producing power twice as large as the height of the reservoir 12.5 meters, the power produced is 3.96 Watts. This is caused because the potential energy generated at the reservoir height of 17 meters is large so that it will affect the kinetic energy in pounding the motion blade (runner). With the increase in kinetic energy that hits the runner, the greater the rotation and the electrical power produced.

Table 3. Data from the comparison of the effect of valve openings on electric power for various reservoir height variations

\begin{tabular}{cccc}
\hline \multirow{2}{*}{$\begin{array}{c}\text { Opening } \\
\text { Valve }\end{array}$} & \multicolumn{3}{c}{ Power (Watt) } \\
\cline { 2 - 4 } & $\begin{array}{c}\text { Head } \\
9 \mathrm{~m}\end{array}$ & $\begin{array}{c}\text { Head } \\
12.5 \mathrm{~m}\end{array}$ & $\begin{array}{c}\text { Head } \\
17 \mathrm{~m}\end{array}$ \\
\hline $18^{\circ}$ & 0 & 0.013 & 0.0208 \\
\hline $32^{\circ}$ & 0.015 & 0.115 & 0.5253 \\
\hline $54^{\circ}$ & 0.243 & 0.48 & 1.312 \\
\hline $72^{\circ}$ & 0.66 & 1.131 & 2.5944 \\
\hline $90^{\circ}$ & 1.209 & 1.935 & 3.96 \\
\hline
\end{tabular}

4. Correlation of Valve Openings to System Efficiency for Reservoir Height Variations

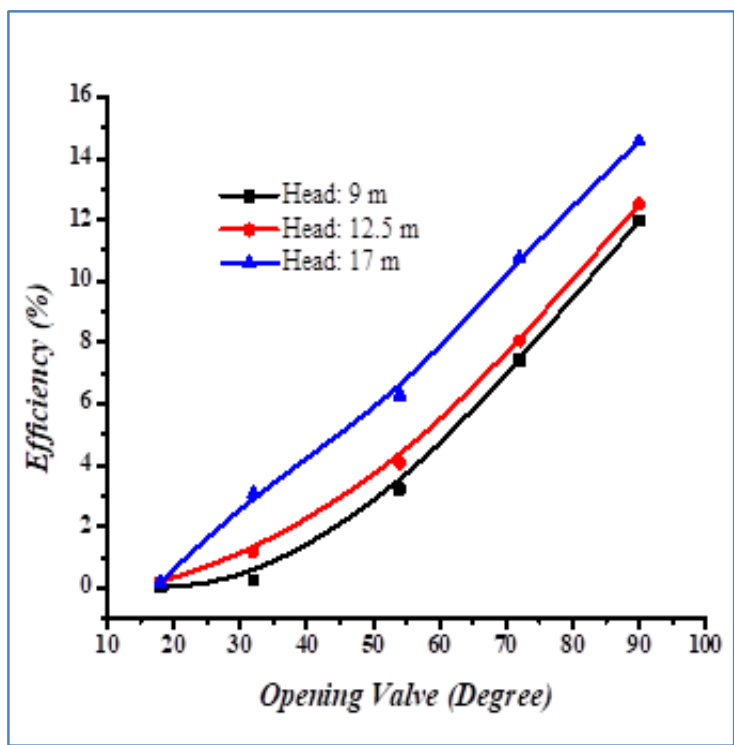

Figure 6. Effect of valve openings on the system efficiency for various reservoir height variations

In general, it can be seen that with a larger valve opening, the efficiency of the system produced is also large, as shown in figure 6 . The figure shows that at the smallest valve opening $\left(18^{\circ}\right)$ with a reservoir height of 9 meters it has a system efficiency of $0 \%$ because there is no power generated at variations in reservoir height and valve openings. While at the largest valve openings $\left(90^{\circ}\right)$ with the same reservoir height, the resulting system efficiency reaches $11.958 \%$. This shows an increase in system efficiency when the valve is opened wider. Similarly, what happens at the height of the reservoir 9 meters, at the height of the reservoir 12.5 meters with the smallest valve openings $\left(18^{\circ}\right)$ the system efficiency is $0.196 \%$ and the system efficiency increases to $12.518 \%$ at the largest valve openings $\left(90^{\circ}\right)$. Likewise at the reservoir height of 17 meters, with the smallest valve openings $\left(18^{\circ}\right)$ the resulting system efficiency is $0.176 \%$ while at the $90^{\circ}$ valve opening the efficiency increases also becomes $14.563 \%$. This is because when the valve is opened wide the quantity of flowing water will be greater. According to the law of Continuity 
if the quantity of water flowing is greater, the efficiency of the system produced is also large because of the electricity and discharge power also increase. With the data above, it can be said that with variations in reservoir height and valve openings can present efficiency data that varies according to the variations used, as shown in table 4 . Of the three variations in the height of the reservoir, a reservoir with a height of 17 meters produces a highefficiency system compared to other heights, namely the height of 12.5 meters and 9 meters.

Table 4. Data from the comparison of the effect of valve openings on the system efficiency for various reservoir height variations

\begin{tabular}{cccc}
\hline \multirow{2}{*}{$\begin{array}{c}\text { Opening } \\
\text { Valve }\end{array}$} & \multicolumn{3}{c}{ Efficiency $(\%)$} \\
\cline { 2 - 4 } & $\begin{array}{c}\text { Head } \\
9 \mathrm{~m}\end{array}$ & $\begin{array}{c}\text { Head } \\
12.5 \mathrm{~m}\end{array}$ & $\begin{array}{c}\text { Head } \\
17 \mathrm{~m}\end{array}$ \\
\hline $18^{\circ}$ & 0 & 0.196 & 0.176 \\
\hline $32^{\circ}$ & 0.254 & 1.156 & 3.076 \\
\hline $54^{\circ}$ & 3.211 & 4.07 & 6.283 \\
\hline $72^{\circ}$ & 7.425 & 8.054 & 10.775 \\
\hline $90^{\circ}$ & 11.958 & 12.518 & 14.563 \\
\hline
\end{tabular}

\section{Duration of Laptop Battery Charging With Pico-Hydro System}

By using the reservoir height of 17 meters and the largest valve opening $\left(90^{\circ}\right)$, the power generated is connected to the battery which after that is converted to an inverter to convert the voltage to 220 volts with alternating current (AC). Then the energy used to charge the laptop. With a duration of 2 hours 18 minutes or 138 minutes, the laptop battery can be fully charged $100 \%$ from the initial condition of $0 \%$ using the Pico-hydro system in this study, as shown in figure 7 . This shows that there is a similarity in the duration of laptop battery charging between using the Picohydro system in this study with the use of electricity from PLN. So this experiment that has been done can be used as a new source of natural energy.

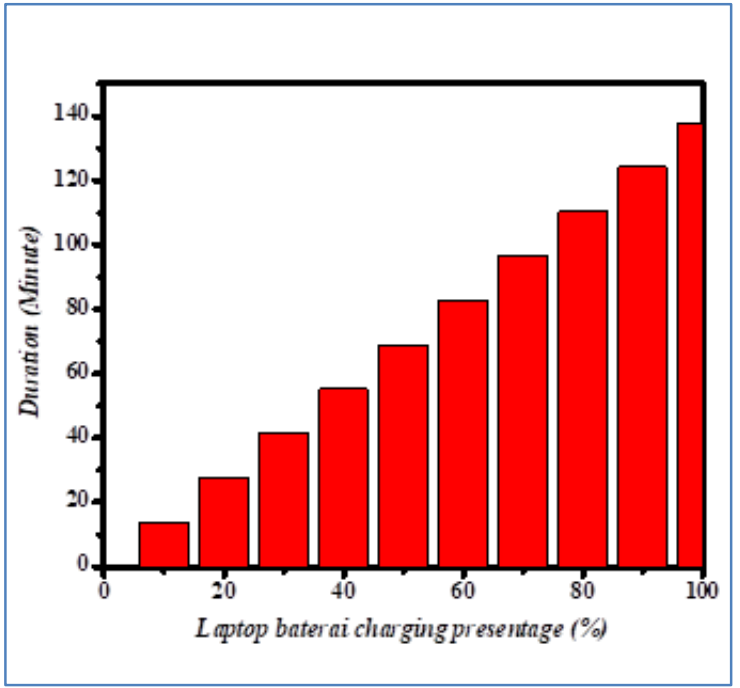

Figure 7. Laptop charging durations

\section{Conclusions}

Based on the research that has been done with variations in reservoir height and valve openings, it can be concluded that; Valve openings and reservoir height variations have been shown to influence the electrical power produced. In this study, the $90^{\circ}$ valve openings have the highest power of 3.96 Watt at a reservoir height of 17 meters; The greatest system efficiency occurs when the valve opening is $90^{\circ}$ at the reservoir height of 17 meters which is equal to $14.56 \%$.

With the results obtained in this study, it is expected to be useful for the development of alternative energy sources, especially in Indonesia, which is one of the countries that have abundant water resources.

\section{References}

[1]. Budiarso, Warjito, Lubis, M. N., \& Adanta, D. (2019). Performance of a Low Cost Spoon-Based Turgo Turbine for Pico Hydro Installation. Energy Procedia, 156, 447451.

[2]. Trisasiwi, W., Masrukhi, Mustofa, A., \& Furqon. (2017). Rancang bangun Turbin Cross-Flow Untuk Pembangkit Listrik Tenaga 
Mikrohidro (PLMTH) Skala

Laboratorium. DINAMIKA

REKAYASA, 13(1), 28-36.

[3]. Descotte, G. (2016). Pico hydro turbines for electricity in rural areas. Field Actions Science Reports, 15, 26-33.

[4]. FAO. (2003). Review of World Water Resources by Country. Rome: FAO.

[5]. Lahimer, A. A., Alghoul, M. A., Sopian, K., Amin, N., Asim, N., \& Fadhel, M. I. (2012). Research and development aspects of pico-hydro power. Renewable and Sustainable Energy Reviews, 16(8), 5861-5878.

[6]. Powell, D., Ebrahimi, A., Nourbakhsh, S., Meshkahaldini, M., \& Bilton, A. M. (2018). Design of pico-hydro turbine generator systems for selfpowered electrochemical water disinfection devices. Renewable Energy, 123, 590-602.

[7]. Bustami, \& Multi, A. (2017). Rancang Bangun Pembangkit Listrik Pikohidro 1000 VA Dengan Memanfaatkan Pembuangan Air Limbah Pada Gedung Pakarti Centre. Paper presented at the SEMNASTEK 2017, Fakultas Teknik Universitas Muhammadiyah Jakarta.

[8]. Agar, D., \& Rasi, M. (2008). On the use of a laboratory-scale Pelton wheel water turbine in renewable energy education. Renewable Energy, 33(7), 1517-1522.

[9]. Williamson, S. J., Stark, B. H., \& Booker, J. D. (2013).
Performance of a low-head pico-hydro Turgo turbine. Applied Energy, 102, 11141126

[10]. Irawan, H., Syamsuri, \& Qurniawan, R. (2018). Analisa Performansi Sistem Pembangkit Listrik Tenaga Air Jenis Turbin Pelton Dengan variasi Bukaan Katup dan Beban Lampu. Hasil Penelitian LPPM UNTAG Surabaya, 3, 27-31.

[11]. Syamsuri, Maulana, H. S., \& Sulisyanto, A. (2018). Experimental Study Of Variation Of The Effect Of The Pelton Turbine Valve Opening On Electricity Energy That Was Produced To Turned On A Laptop. VANOS Journal Of Mechanical Engineering Education, 3(2), 156-162. 